\title{
Genotypic Characterization of Virulent Rhodococcus equi Isolated from the Environment of Hokkaido Native Horses in Hakodate, Hokkaido
}

\author{
Shinji TAKAI ${ }^{1}$, Fumiko HATORI ${ }^{1}$, Tsutomu KAKUDA ${ }^{1}$, Yukako SASAKI ${ }^{1}$, Shiro TSUBAKI $^{1}$ and \\ Hiroshi MIYAKAMI ${ }^{2}$ \\ ${ }^{1}$ Department of Animal Hygiene, School of Veterinary Medicine and Animal Sciences, Kitasato University, \\ Towada, Aomori 034-8628, ${ }^{2}$ The Preservation Association of Hokkaido Native Horse, Donan Branch, Takaoka, \\ Hakodate, Hokkaido 042-0955, Japan
}

\begin{abstract}
Rhodococcus equi was isolated from soil samples obtained from seven Hokkaido native horse farms in Hakodate, Hokkaido. R. equi was prevalent in all 59 soil samples collected from the seven farms at concentrations of between $7.5 \times 10^{2}$ and $7.5 \times 10^{4}$ colony-forming units per gram of soil. The isolates were examined for presence of the gene that encodes the virulenceassociated 15-17 kDa antigen protein, VapA, using PCR. VapA-positive R. equi was isolated from 1-6\% of isolates from three of the farms. This represents $1.4 \%$ of isolates from all farms examined (8 out of 590). The eight virulent isolates were characterized by plasmid profiling, restriction fragment length polymorphism analysis, and pulsed-field gel electrophoresis. All of the virulent isolates contained an 87-kb type II plasmid, but there were eight distinct VspI profiles. These results suggest that, although the Hokkaido horses of Hakodate are exposed to a variety of distinct types of virulent $R$. equi, the incidence of exposure is low or zero. An 87-kb type II plasmid was strongly associated with Hokkaido native horses as has already been observed in virulent isolates from Hokkaido native horses at Bekkai, Hokkaido.

Key words: Hokkaido, horse, plasmid, Rhodococcus equi, virulence
\end{abstract}

\author{
J. Equine Sci. \\ Vol. 16, No. 2 \\ pp. 29-34, 2005
}

\begin{abstract}
Rhodococcus equi is one of the most harmful bacterial pathogens for 1- to 3-month-old foals. Infections caused by this organism are characterized by chronic, suppurative bronchopneumonia, which is often accompanied by ulcerative enteritis and mesenteric lymphadenitis [14, 18]. Since the first report in 1949 by Harakawa and Morita [5] of R. equi infection in Japanese foals in Aomori, the occurrence of the disease in the northern part of Japan, especially in Aomori and Hokkaido, has been described $[7,11,22]$. The discovery of virulence-associated antigens and virulence plasmids has elucidated the virulence of $R$. equi [18, 24, 29 , 32]. Virulent $R$. equi, which is characterized by VapA and a virulence plasmid of $85-90 \mathrm{~kb}$, has been isolated from the lesions of infected foals and can reproduce the disease under experimental conditions
\end{abstract}

This article was accepted April 4, 2005

*Corresponding author
[30, 34]. However, avirulent R. equi, which has no virulence-associated antigens or plasmids, does not cause the disease and is widely distributed in horses and their environment [19, 27]. The disease generally occurs sporadically, becoming endemic on farms that are heavily contaminated with virulent $R$. equi $[14,18$, 28].

Molecular epidemiological studies on the virulence plasmids of $R$. equi have been conducted in several countries, including Japan [2, 4, 8, 9, 12, 13, 15, 16, 20, 21, 25, 26, 30, 31, 36]. Restriction-enzyme digestion patterns of virulence plasmids from foals and their environmental isolates have been used to categorize them into 12 closely related types. These studies have revealed differences between the geographic distributions of various virulence plasmids. These differences exist on a global scale and within Japan [2, $4,8,9,12,13,15,16,20,21,25,26,30,31,36]$.

Hokkaido horses are popularly known as dosanko in 
Japan. In the fifteenth century, people from mainland Japan settled in Hokkaido, bringing horses with them [6]. These horses were mainly the offspring of Nanbu horses from the Tohoku breeding district [6]. Hokkaido is now the most important district for racehorse breeding in Japan. Molecular epidemiological studies on virulent $R$. equi in Thoroughbred foals and their environment have been conducted in Hidaka, Hokkaido [19, 22], but little is known about the prevalence of virulent $R$. equi in Hokkaido native horses in Hakodate, where the horses from the Tohoku region were originally brought ashore. The purpose of this study was to quantify the prevalence of virulent $R$. equi on Hokkaido horse stud farms and to characterize it using plasmid profiling, restriction fragment length polymorphism (RFLP) analysis, and pulsed-field gel electrophoresis (PFGE).

\section{Materials and Methods}

\section{Bacterial strains}

The following bacterial reference strains of $R$. equi were used in this study: ATCC 33701 (85-kb type I), 96E35 (85-kb type II), T47-2 (85-kb type III), T43 (85kb type IV), 222 (87-kb type I), 96B6 (87-kb type II), Brazil (87-kb type III), L1 (90-kb type I), S11-8 (90-kb type II), Kuma83-3 (90-kb type III), Kuma83-10 (90-kb type IV) and J21-2 (90-kb type V) [16, 20, 25, 26, 30, 31].

\section{Collection and isolation of R. equi from soil}

Fifty-nine soil samples were collected from seven farms in Hakodate, Hokkaido, as shown in Table 1. A small spoon was used to scrape soil samples from the surface of the ground and each sample was poured into a sterile tube. One gram of the soil was serially diluted with a 10 -fold volume of sterile saline. Each dilution was inoculated onto two plates of nalidixic acidnovobiocin-actidione (cycloheximide)-potassium tellurite (NANAT) medium as previously described [35]. The plates were incubated at $30^{\circ} \mathrm{C}$ for two or three days. The $R$. equi colonies were counted and the numbers of viable organisms per gram of soil were estimated.

\section{Polymerase chain reaction}

Suspected colonies of $R$. equi were subcultured and examined for the presence of the 15-17 kDa antigen (VapA) gene using PCR. Published sequences of the VapA gene (GenBank database accession number D212361) from the $R$. equi strain, ATCC 33701, were used as target DNA for polymerase chain reaction (PCR) amplification [17]. Primer 1 (5'GACTCTTCACAAGACGGT-3') corresponded to the sense strand at positions 6-23, and primer 2 (5'TAGGCGTTGTGCCAGCTA-3') corresponded to the antisense strand at positions 569-552 in the sequence of the 15-17 kDa antigen gene [17]. PCR amplification was performed as described previously [23].

\section{Isolation of plasmid DNA}

Plasmid DNA was isolated from $R$. equi by the alkaline lysis method [3] with modifications as described previously [32]. Plasmid DNA was digested with the restriction endonucleases BamHI, EcoRI, EcoT22I, and HindIII for estimation of plasmid size. Samples of plasmid preparations were separated on $0.7 \%$ or $1.0 \%$ agarose gels at approximately $5 \mathrm{~V} / \mathrm{cm}$ for $2 \mathrm{hr}$.

Analysis of chromosomal DNA restriction pattern using pulsed field gel electrophoresis

The isolates of R. equi were transferred to a $\mathrm{BHI}$

Table 1. Isolation of virulent R. equi from soil samples on Hokkaido stud farms

\begin{tabular}{|c|c|c|c|c|c|c|}
\hline Farm & $\begin{array}{l}\text { No. of soil } \\
\text { samples }\end{array}$ & $\begin{array}{c}\text { No. of positive } \\
\text { cultures }\end{array}$ & $\begin{array}{l}\text { Range of the } \\
\text { number of } R \text {. equi } \\
\text { per gram of soil }\end{array}$ & $\begin{array}{l}\text { No. of } \\
\text { isolates }\end{array}$ & $\begin{array}{c}\text { No. of } \\
\text { virulent isolates }\end{array}$ & $\begin{array}{c}\text { Virulence } \\
\text { plasmid type }\end{array}$ \\
\hline $\mathrm{Su}$ & 10 & 10 & $4.4 \times 10^{3}-4.7 \times 10^{4}$ & 100 & 1 & $87 \mathrm{~kb}$ type II \\
\hline Oo & 10 & 10 & $1.5 \times 10^{3}-1.7 \times 10^{4}$ & 100 & 4 & $87 \mathrm{~kb}$ type II \\
\hline Do & 10 & 10 & $1.1 \times 10^{3}-2.8 \times 10^{4}$ & 100 & 0 & - \\
\hline $\mathrm{Se}$ & 10 & 10 & $7.5 \times 10^{2}-6.1 \times 10^{3}$ & 100 & 0 & - \\
\hline Ts1 & 5 & 5 & $3.3 \times 10^{3}-6.4 \times 10^{3}$ & 50 & 3 & $87 \mathrm{~kb}$ type II \\
\hline Ts2 & 6 & 6 & $3.3 \times 10^{3}-1.1 \times 10^{4}$ & 60 & 0 & - \\
\hline $\mathrm{Sa}$ & 8 & 8 & $5.7 \times 10^{3}-7.5 \times 10^{4}$ & 80 & 0 & - \\
\hline Total & 59 & 59 & - & 590 & 8 & - \\
\hline
\end{tabular}


broth and incubated for $36 \mathrm{hr}$ at $30^{\circ} \mathrm{C}$ in a shaking incubator. Bacterial cells were washed and resuspended in SE buffer (25 mM EDTA, $75 \mathrm{mM} \mathrm{NaCl}$; $\mathrm{pH} 7.5$ ). Agarose plugs were made from a 1:1 mixture of $2 \%$ low-melting-point agarose and the cell suspension. The plugs were lysed in a resuspension buffer, which contained lysozyme $(20 \mathrm{mg} / \mathrm{m} l)$, for 18 $\mathrm{hr}$ at $37^{\circ} \mathrm{C}$. The cells were then treated for $24 \mathrm{hr}$ at $50^{\circ} \mathrm{C}$ with the same volume of a solution $(50 \mathrm{mM}$ Tris$\mathrm{HCl}, 50 \mathrm{mM}$ EDTA, $1 \% \mathrm{vol} / \mathrm{vol}$ lauroyl sarcosine; $\mathrm{pH}$ 9.0) containing proteinase $\mathrm{K}(300 \mu \mathrm{g} / \mathrm{m} l)$ and were washed three times with Tris-EDTA buffer. VspI (MBI Fermentas) was used for restriction endonuclease digestion in accordance with the instructions of the manufacturer. The fragments were resolved by PFGE in electrophoresis-grade agarose (1\%; Pharmacia Biotech) using a CHEF-MAPPER system (Bio-Rad). The following conditions were applied: running time, $22 \mathrm{hr}$; temperature, $14^{\circ} \mathrm{C}$; voltage gradient, $200 \mathrm{~V}$; included angle, $120^{\circ}$. During the first run $(7 \mathrm{hr})$, an initial pulse time of $6 \mathrm{~s}$ and a final pulse time of $15 \mathrm{~s}$ was used, and during the second run ( $15 \mathrm{hr}$ ), an initial pulse time of $23 \mathrm{~s}$ and a final pulse time of $40 \mathrm{~s}$ was used. The gels were stained with ethidium bromide $(0.5 \mu \mathrm{g} /$ $\mathrm{ml}$ ) for $15 \mathrm{~min}$, destained in distilled water, and photographed under UV light. Mid Range PFG Maker II (New England Bio Labs) was used for estimation of molecular size.

\section{Results}

Isolation of $R$. equi from soil samples from Hokkaido horse farms:

R. equi was cultured from soil samples collected in
Hakodate, Hokkaido, from seven farms at which the only horse breed present was the Hokkaido horse (Table 1). All 59 of the soil samples from the seven farms were positive for $R$. equi. The number of $R$. equi ranged from $7.5 \times 10^{2}$ to $7.5 \times 10^{4}$ colony-forming units per gram of soil. Ten colonies per sample were subcultured; 590 colonies were identified and tested by PCR for the gene that encodes VapA. Positive colonies were then tested for the presence of virulence plasmids. As shown in Table 1, virulent $R$. equi was present in 1$6 \%$ of isolates taken from three of the farms, representing $1.4 \%$ of all isolates ( 8 out of 590 ).

Genotyping of virulent $R$. equi from Hokkaido native horses

Plasmid DNA from the eight isolates was digested with the restriction endonucleases BamHI, EcoRI, EcoT22I, and HindIII. All of the digestion patterns were those of an 87-kb type II plasmid (Table 2). PFGE patterns of the eight isolates were compared to assess the genetic diversity of VapA-positive $R$. equi isolates containing an 87-kb type II plasmid in Hokkaido horses. PFGE yielded eight distinct VspI profiles (Fig. 1).

\section{Discussion}

Our study demonstrates that Hokkaido native horses in Hakodate are exposed to virulent $R$. equi with a variety of distinct PFGE types, but the presence of these is low. An 87-kb type II plasmid was strongly associated with Hokkaido native horses.

In recent studies, we showed differences in the geographic distribution of virulence-associated plasmids found in the Americas, Europe, Australia, Africa, and Japan $[2,4,8,9,12,13,15,16,20,21,25,26$,

Table 2. Comparison of the virulence plasmid ratios of vapA-positive Rhodococcus equi isolates from Hokkaido, Aomori, Kiso, Misaki, Kagoshima, Kumamoto, and Jeju, Korea

\begin{tabular}{|c|c|c|c|c|c|c|c|c|}
\hline Breed & Location & $\begin{array}{l}\text { 87-kb } \\
\text { type II }\end{array}$ & $\begin{array}{l}90-\mathrm{kb} \\
\text { type I }\end{array}$ & $\begin{array}{l}90-\mathrm{kb} \\
\text { type II }\end{array}$ & $\begin{array}{c}\text { 90-kb } \\
\text { type III }\end{array}$ & $\begin{array}{l}\text { 90-kb } \\
\text { type IV }\end{array}$ & $\begin{array}{l}\text { 90-kb } \\
\text { type V }\end{array}$ & Reference \\
\hline Hokkaido & Hakodate & (0) & - & - & - & - & - & This study \\
\hline Hokkaido & Bekkai & (0) & - & - & - & - & - & Takai et al.[26] \\
\hline Kiso & Nagano & 0 & - & (0) & - & - & - & Takai et al.[26] \\
\hline Misaki & Miyazaki & - & (O) & - & - & - & - & Takai et al. [26] \\
\hline Thoroughbred & Hidaka, & (O) & 0 & - & - & - & - & Takai et al.[22] \\
\hline Thoroughbred & Aomori & (O) & O & 一 & - & 一 & - & Takai et al.[22] \\
\hline Thoroughbred & Kagoshima & 一 & (O) & - & 0 & $\mathrm{O}$ & - & Yuyama et al. [36] \\
\hline Crossbred & Kumamoto & - & - & - & O & O & - & Takai et al. [25] \\
\hline Cheju & Korea & - & - & O & - & - & (O) & Takai et al.[31] \\
\hline
\end{tabular}

(O), major isolates (more than $50 \%$ of isolates); $\bigcirc$, minor isolates; - , not found. 


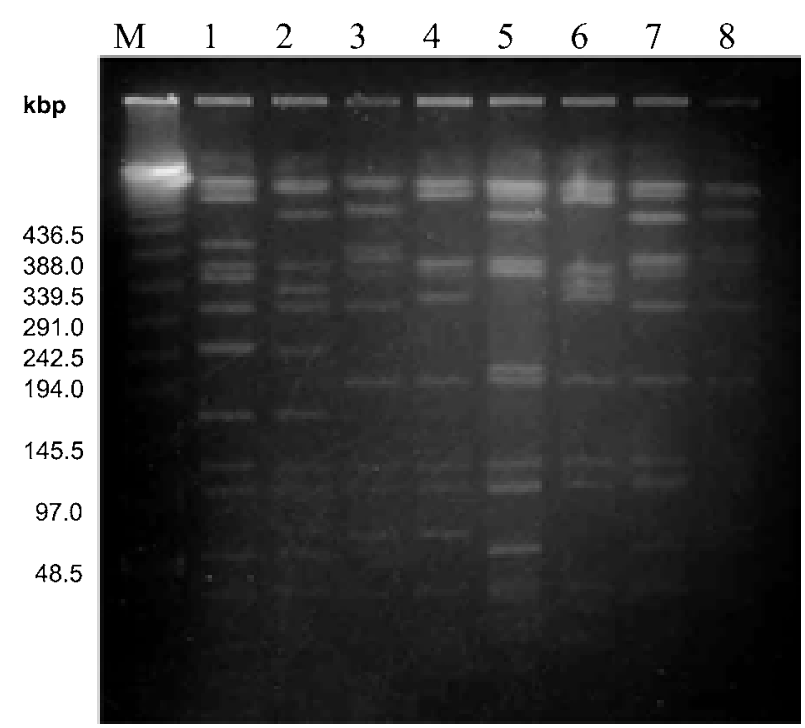

Fig. 1. PFGE patterns of Rhodococcus equi isolates from Hakodate. Lanes: 1, Mid Range PFG Maker II; 2, isolate 11-4 (87-kb type II); 3, isolate 19-2 (87-kb type II); 4, isolate $21-3$ (87-kb type II); 5 , isolate $21-10$ (87-kb type II); 6 , isolate 22-2 (87-kb type II); 7, isolate $45-1$ (87-kb type II); 8 , isolate $45-5$ (87-kb type II); 9 , isolate $46-3$ (87-kb type II).

30, 31, 36]. Most clinical isolates from the Americas, Australia, and Europe contain 85-kb type I or 87-kb type I plasmids. The 85-kb type II, III, IV, and V plasmids are unique to France, Texas, Tennessee, and Brazil, respectively [15, 20, 30, 33]. On the other hand, the 87kb type II and 90-kb type I, II, III and IV plasmids have only been found in clinical or environmental isolates from Japan, and 90-kb type II and V plasmids have only been found in those from Korea [25, 30, 31, 36].

Surveillance studies of virulent $R$. equi have been conducted in Thoroughbred horses and native horses in Japan (Table 2). Virulent isolates from Thoroughbred horses in Hokkaido and Aomori contained an 87-kb type II or a $90-\mathrm{kb}$ type I plasmid. The ratio of $87-\mathrm{kb}$ type II plasmids to $90-\mathrm{kb}$ type I plasmids in the clinical and environmental isolates in Hidaka was about 3 to 1 . Interestingly, virulent isolates from Thoroughbred horses in Kagoshima contained a 90-kb type I, III, or IV plasmid, and most of the isolates contained a $90-\mathrm{kb}$ type I plasmid. In our previous study, Japanese native horse breeds (Hokkaido, Kiso, Noma, Misaki, Tokara, Miyako, and Yonaguni) were also examined, but virulent isolates were isolated only from the Hokkaido, Kiso and Misaki breeds [26]. Hokkaido isolates in Bekkai contained an 87-kb type II plasmid, and Kiso isolates contained an 87-kb type II plasmid and a $90-\mathrm{kb}$ type II plasmid. Misaki isolates contained a 90-kb type I plasmid. These results suggest that there are differences in the geographic distribution of virulence plasmids within Japan, viz. that the 90-kb plasmids are dominant in the western part of Japan, and an $87-\mathrm{kb}$ type II plasmid is dominant in the northern part of Japan.

The Hokkaido breed is thought to be descended from the Nanbu native breed, but the Nanbu breed is now extinct in the Tohoku region today [6]. However, as the $87-\mathrm{kb}$ type II plasmid was predominant in isolates from Aomori (Table 2), it may have been introduced to the island of Hokkaido by Nanbu horses imported from the Tohoku region during the past 300 years.

There has been a report of an outbreak of $R$. equi infection in Hokkaido native horses [26]. According to a field survey conducted by local veterinarians in Hakodate, the disease was not recognized, as it had not occurred there before. The prevalence of virulent $R$. equi at the seven farms surveyed was comparatively low or absent compared with that at Thoroughbred horsebreeding farms in Hokkaido [18, 19]. Furthermore, eight isolates showed distinct PFGE patterns. An infected foal may shed a large amount of virulent $R$. equi in the feces, in which it may multiply. Contamination of the environment with monoclonal organisms of virulent $R$. equi may also occur via the lesions. Supporting this concept, PFGE analysis of clinical isolates collected in Australia demonstrated that there are different strains of $R$. equi that carry the VapA gene. These strains tended to be widespread on the farms that were examined in this study, but particular strains were associated with individual farms [10]. The present study detected eight distinct genotypic isolates of virulent $R$. equi in samples taken from three farms. This suggests that $R$. equi infection will not become a problem in Hokkaido native foals in the future. In conclusion, virulent $R$. equi organisms were introduced by native horses in the past and are presently being transferred between horse-breeding regions in Japan by Thoroughbred horses.

\section{Acknowledgments}

This study was supported by a grant-in-aid for general scientific research (Takai:14405031, 16380208) from the Ministry of Education, Culture, Sports, Science, and 
Technology of Japan.

\section{References}

1. Barton, M.D. and Hughes, K.L. 1980. Corynebacterium equi: a review. Vet. Bull. 50: 65-80.

2. Becu, T., Kakuda, T., Tsubaki, S., and Takai, S. 2000. Prevalence of virulent Rhodococcus equi in isolates from soil collected from 5 horse-breeding farms in Argentina. J. Equine Sci. 11: 23-27.

3. Birnboim, H.C. and Doly, J. 1979. A rapid alkaline extraction procedure for screening recombinant plasmid DNA. Nucleic Acids Res. 7: 1513-1523.

4. Haites, R., Muscatello, G., Begg, A., and Browning, G.F. 1997. Prevalence of the virulence-associated gene of Rhodococcus equi in isolates from infected foals. J. Clin. Microbiol. 35: 1642-1644.

5. Harakawa, T. and Morita, S. 1949. Observations on Corynebacterium equi isolated from abscesses occurring in the lungs of foals. Jpn. J. Vet. Sci. 11: 63-74.

6. Hendricks, B.L. 1995. Hokkaido. pp.223-224. In: International Encyclopedia of Horse Breeds, University of Oklahoma Press, London.

7. Ishino, S., Kumagai, K., Kuniyoshi, S., Nakazawa, M., Matsuda, I., and Oka, M. 1992. Immunohistochemical observations on pneumonic lesions caused by Rhodococcus equi in foals. J. Vet. Med. Sci. 54: 509-515.

8. Makrai, L., Takai, S., Tamura, M., Tsukamoto, A., Sekimoto, R., Sasaki, Y., Kakuda, T., Tsubaki, S., Varga, J., Fodor, L., Solymosi, N., and Major, A. 2002. Characterization of virulence plasmid types in Rhodococcus equi isolates from foals, pigs, humans and soil in Hungary. Vet. Microbiol. 88: 377-384.

9. Martens, R.J., Takai, S., Cohen, N.D., Chaffin, M.K., Liu, H., Sakurai, K., Sugimoto, H., and Lingsweiler, S. 2000. Rhodococcus equi: Prevalence and virulence in foals with spontaneous pneumonia and soil of horse-breeding farms in Texas. J. Am. Vet. Med. Assoc. 217: 220-225.

10. Morton, A.C., Begg, A.P., Anderson, G.A., Takai, S., Lammler, C., and Browning, G.F. 2001. Epidemiology of Rhodococcus equi strains on Thoroughbred horse farms. Appl. Environ. Microbiol. 67: 2167-2175.

11. Nakazawa, M., Isayama, Y., Kashiwazaki, M., and Yasui, T. 1987. Diagnosis of Rhodococcus equi infection in foals by the agar gel diffusion test with protein antigen. Vet. Microbiol. 15: 105-113.
12. Nicholson, V.M. and Prescott, J.F. 1997. Restriction enzyme analysis of the virulence plasmids of VapA-positive Rhodococcus equi strains isolated from humans and horses. J. Clin. Microbiol. 35: 738-740.

13. Ozgur, Y., Ikiz, S., Carioglu, B., Ilgaz, A., and Takai, S. 2000. Two cases of dead foals associated with Rhodococcus equi pneumonia in Turkey; analysis of plasmid profiles from isolated strains. $J$. Equine Sci. 11: 1-5.

14. Prescott, J.F. 1991. Rhodococcus equi: an animal and human pathogen. Clin. Microbiol. Rev. 4: 20-34.

15. Rahal, K., Kodjo, A., Gretzel, D., and Richard, Y. 1999. Isolation of a new type of virulence plasmid DNA in Rhodococcus equi strains from horses and equine environments in France. Rev. Med. Vet. 150: 349-352.

16. Ribeiro, M.G., Seki, I., Yasuoka, K., Kakuda, T., Sasaki, Y., Tsubaki, S., and Takai, S. 2005. Molecular epidemiology of virulent Rhodococcus equi from foals in Brazil: virulence plasmids of 85kb type I, 87-kb type I, and a new variant, $87-\mathrm{kb}$ type III. Comp. Immunol. Microbiol. Infect. Dis. 28: 53-61.

17. Sekizaki, T., Takai, S., Egawa, Y., Ikeda, T., Ito, H., and Tsubaki, S. 1995. Sequence of the Rhodococcus equi gene encoding the virulence-associated 1517-kDa antigens. Gene 155: 135-136.

18. Takai, S. 1997. Epidemiology of Rhodococcus equi infections: a review. Vet. Microbiol. 56: 167-176.

19. Takai, S., Anzai, T., Yamaguchi, K., Kakizaki, S., Takahagi, J., Sato, Y., Takehara, F., Tamada, Y., Matsukura, S., Tani, A., Kato, M., Seno, N., Sasaki, Y., Tsubaki, S., and Kamada, M. 1994. Prevalence of virulence plasmids in environmental isolates of Rhodococcus equi from horse-breeding farms in Hokkaido. J. Equine Sci. 5: 21-25.

20. Takai, S., Chaffin, M.K., Cohen, N.D., Hara, M., Nakamura, M., Kakuda, T., Sasaki, Y., Tsubaki, S., and Martens, R.J. 2001. Prevalence of virulent Rhodococcus equi in soil from $5 R$. equi-endemic horse-breeding farms and restriction fragment length polymorphisms of virulence plasmids in isolates from soil and infected foals in Texas. J. Vet. Diag. Invest. 13: 489-494.

21. Takai, S., Henton, M.M., Picard, J.A., Guthrie, A.J., Fukushi, H., and Sugimoto, C. 2001. Prevalence of virulent Rhodococcus equi in isolates from soil collected from 2 horse farms in South Africa and restriction fragment length polymorphisms of virulence plasmids in the isolates from infected foals, $\operatorname{dog}$ and monkey. Onderstepoort J. Vet. Res. 68: 
$105-110$.

22. Takai, S., Higuchi, T., Matsukura, S., Tamada, Y., Nishio, Y., Morishita, T., Fujii, M., Hidaka, D., Furugori, J., Karasawa, T., Shoda, M., Akita, O., Ogawa, K., Hara, M., Kakuda, T., Sasaki, Y., Tsubaki, S., Hagiwara, S., and Senba, H. 2000. Some epidemiological aspects of Rhodococcus equi infection in foals in Japan: a review of 108 cases in 1992-1998. J. Equine Sci. 11: 7-14.

23. Takai, S., Ikeda, T., Sasaki, Y., Watanabe, Y., Ozawa, T., Tsubaki, S., and Sekizaki, T. 1995. Identification of virulent Rhodococcus equi by amplification of gene coding for 15- to 17 kilodalton antigens. J. Clin. Microbiol. 33: 16241627.

24. Takai, S., Koike, K., Ohbushi, S., Izumi, C., and Tsubaki, S. 1991. Identification of 15- to 17kilodalton antigens associated with virulent Rhodococcus equi. J. Clin. Microbiol. 29: 439-443.

25. Takai, S., Murata, N., Kudo, R., Narematsu, N., Kakuda, T., Sasaki, Y., and Tsubaki, S. 2001. Rhodococcus equi pneumonia in a crossbred foal in Kumamoto: clinical isolates contained new virulence plasmids, 90-kb type III and type IV. Vet. Microbiol. 82: 373-381.

26. Takai, S., Ogawa, K., Fukunaga, N., Sasaki, Y., Kakuda, T., Tsubaki, S., and Anzai, T. 2001. Isolation of virulent Rhodococcus equi from native Japanese horses. Comp. Immun. Microbiol. Infect. Dis. 24: 123-133.

27. Takai, S., Ohbushi, S., Koike, K., Tsubaki, S., Ohishi, H., and Kamada, M. 1991. Prevalence of virulent Rhodococcus equi in isolates from soil and feces of horses from horse-breeding farms with and without endemic infections. J. Clin. Microbiol. 29: 2887-2889.

28. Takai, S., Sasaki, Y., and Tsubaki, S. 1995. Rhodococcus equi infection in foals: current concepts and implications for future research. $J$. Equine Sci. 6: 105-119.

29. Takai, S., Sekizaki, T., Ozawa, T., Sugawara, T., Watanabe, Y., and Tsubaki, S. 1991. Association between a large plasmid and 15- to 17-kilodalton antigens in virulent Rhodococcus equi. Infect. Immun. 59: 4056-4060.

30. Takai, S., Shoda, M., Sasaki, Y., Tsubaki, S., Fortier, G., Pronost, S., Rahal, K., Becu, T., Begg, A., Browning, G., Nicholson, V.M., and Prescott, J.F. 1999. Genetic analysis of virulent Rhodococcus equi based on restriction fragment length polymorphism of virulence plasmids: a molecular approach for epidemiology of virulent $R$. equi in the world. J. Clin. Microbiol. 37: 3417-3420.

31. Takai, S., Son, W.-G., Lee, D.-S., Madarame, H., Seki, I., Yamatoda, N., Kimura, A., Kakuda, T., Sasaki, Y., Tsubaki, S., and Lin, Y.-K. 2003. Rhodococcus equi virulence plasmids recovered from horses and their environment in Jeju, Korea: 90-kb type II and a new variant, 90-kb type V.J. Vet. Med. Sci. 65: 1313-1317.

32. Takai, S., Watanabe, Y., Ikeda, T., Tsubaki, S., Ozawa, T., Matsukura, S., Tamada, Y., and Sekizaki, T. 1993. Virulence-associated plasmids in Rhodococcus equi. J. Clin. Microbiol. 31: 1726-1729.

33. Takai, S., Yamatoda, N., Kimura, A., Sasaki, Y., Kakuda, T., Tsubaki, S., Bemis, D., and Brace, J. J. 2004. Prevalence of virulent Rhodococcus equi in soil environment on a horse-breeding farm in Tennessee, U. S. A. J. Equine Sci. 15: 75-79.

34. Wada, R., Kamada, M., Anzai, T., Nakanishi, A., Kanemaru, T., Takai, S., and Tsubaki, S. 1997. Pathogenicity and virulence of Rhodococcus equi in foals following intratracheal challenge. Vet. Microbiol. 56: 301-312.

35. Woolcock, J.B., Farmer, A-M.T., and Mutimer, M.D. 1979. Selective medium for Corynebacterium equi isolation. J. Clin. Microbiol. 9: 640-642.

36. Yuyama, T., Yusa, S., Yoshizumi, K., Yamano, S., Murata, S., Hirose, T., Osanai, R., Onishi, Y., Osato, S., Sasaki, C., Kakuda, T., Tsubaki, S., and Takai, S. 2002. Molecular epidemiology of virulent Rhodococcus equi in Thoroughbred horses in Kagoshima. J. Vet. Med. Sci. 64: 715-718. 